DOI: https://doi.org/10.24127/ajpm.v10i3.3851

\title{
KEMAMPUAN PEMECAHAN MASALAH SISWA MELALUI STRATEGI MENEBAK DENGAN CERDAS DAN MENGUJINYA
}

\author{
Azka 'Afifah', Cecil Hiltrimartin ${ }^{2 *}$, Somakim³ \\ $1,2^{*}, 3$ Universitas Sriwijaya, Palembang, Indonesia \\ *Corresponding author. Jalan Palembang-Prabumulih KM 32, 30662, Palembang, Indonesia. \\ E-mail: azka_affifah@ymail.com ${ }^{1)}$ \\ $\underline{\text { hiltrimartincecill@gmail.com }}^{2 *)}$
}

Received 24 June 2021; Received in revised form 12 September 2021; Accepted 27 September 2021

\begin{abstract}
Abstrak
Penelitian ini bertujuan untuk mendeskripsikan kemampuan pemecahan masalah siswa setelah diajarkan strategi menebak dengan cerdas dan mengujinya. Jenis penelitian ini adalah penelitian deskriptif. Penelitian ini dilakukan pada siswa kelas X MIPA 4 SMA Negeri 1 Pangkalpinang. Untuk pembahasan yang lebih mendalam, terdapat dua subjek penelitian yang diambil dari siswa yang berada dalam kategori sangat baik dan cukup yang dipilih melalui teknik purposive sampling. Pengumpulan data penelitian ini melalui tes yang kemudian dianalisis sesuai dengan empat tahapan Polya. Hasil penelitian mengungkapkan bahwa siswa yang berada dalam kategori sangat baik dapat melaksanakan keempat tahapan Polya dengan tepat dan dapat mengaplikasikan dengan baik strategi menebak dengan cerdas dan mengujinya dalam menyelesaikan permasalahan. Sedangkan siswa yang berada dalam kategori cukup baru mampu memahami permasalahan dengan baik dan masih terdapat kesalahan dalam mengaplikasikan strategi menebak dengan cerdas dan mengujinya.
\end{abstract}

Kata kunci: Kemampuan pemecahan masalah; pembelajaran pemecahan masalah; strategi menebak dengan cerdas dan mengujinya.

\begin{abstract}
This study aims to describe the problem-solving abilities of students after taught intelligent guessing and testing strategy. This study is descriptive research. This study was conducted on students of X MIPA 4 SMA Negeri 1 Pangkalpinang. For further discussion, there were two subjects from student who was in very good category and sufficient category were chosen using purposive sampling technique. The data collected through test, then analyzed according to the four stages of Polya. The result of this study show that student in very good category was able to do four stages of Polya correctly and able to apply the intelligent guessing and testing strategy to solve the problem. Meanwhile, student in sufficient category only able to understanding the problem correctly and still there was something wrong in applying the intelligent guessing and testing strategy.
\end{abstract}

Keywords: Intelligent guessing and testing strategy; problem-solving abilities; problem-solving learning.

This is an open access article under the Creative Commons Attribution 4.0 International License

\section{PENDAHULUAN}

Masalah adalah hal yang tidak bisa dipungkiri keberadaannya, tak terkecuali dalam pembelajaran matematika (Wahyudi \& Anugraheni,
2017). Dalam memecahkan masalah, siswa menggunakan berbagai strategi penyelesaian yang telah diketahui dan seringkali mereka akan menemukan pengetahuan baru pada saat proses 
pemecahan masalah (NCTM, 2000). Mempunyai kemampuan pemecahan masalah yang baik merupakan salah satu tujuan pembelajaran matematika yang tertuang dalam Permendikbud Nomor 21 Tahun 2016.

Pembelajaran pemecahan masalah di Indonesia sayangnya masih belum berjalan secara maksimal (Isharyadi, 2018; Novitasari \& Wilujeng, 2018). Faktor-faktor yang mempengaruhi rendahnya kemampuan pemecahan masalah siswa Indonesia adalah siswa tidak terbiasa dalam menyelesaikan soal pemecahan masalah, minimnya pengetahuan siswa terkait strategi pemecahan masalah, dan kurangnya keterlibatan intuisi dalam pembelajaran (Putra et al., 2018; Sari, 2016; Zulfitri et al., 2019). Padahal, intuisi memiliki peran penting dalam pembelajaran, memiliki intuisi yang tinggi dapat memudahkan siswa dalam menyelesaikan masalah (Sari, 2016; Azmi, 2017; Susilawati et al., 2017; Mutia et al., 2021).

Intuisi merupakan aktivitas dengan proses "yang tidak biasa" karena adanya lompatan pemikiran akibat dari tidak ditemukannya jalur logis yang menghubungkan fakta dengan gagasan yang ada atau secara sederhana intuisi dipahami sebagai teknik menebak (Sukmana, 2011). Strategi pemecahan masalah yang berkaitan dengan menebak adalah strategi menebak dengan cerdas dan mengujinya (Budhi \& Kartasasmita, 2015).

Strategi menebak dengan cerdas dan mengujinya akan membantu siswa menemukan solusi permasalahan dengan mempersempit pilihan jawaban yang selanjutnya akan diuji apakah solusi tersebut sesuai dengan situasi permasalahan yang dihadapi (Polya, 1973). Tidak hanya menebak secara acak, siswa akan menggunakan kecerdasannya agar tidak berkali-kali melakukan pengujian saat mencari solusi permasalahan yang tepat (Hartono, 2014).

Penggunaan strategi menebak dengan cerdas dan mengujinya tepat digunakan untuk permasalahan yang berkaitan dengan persamaan dan variabel (Damayanti, 2017; Ayuningrum \& Setiawan, 2018; Asy'ari et al., 2020). Salah satu materi yang ada di Kurikulum 2013 yang memliki persamaan dan variabel adalah Sistem Persamaan Linear Tiga Variabel.

Beberapa hasil penelitian mengungkapkan bahwa dengan mengajarkan siswa strategi, akan meningkatkan kemampuan pemecahan masalah siswa karena dengan strategi dapat memudahkan siswa menyelesaikan permasalahan (Riffyanti \& Setiawan, 2017; Ayuningrum \& Setiawan, 2018).

Namun masih sedikit penelitian mengenai pengajaran strategi pemecahan masalah terutama strategi menebak dengan cerdas dan mengujinya. Oleh karena itu, tujuan penelitian ini adalah untuk mendeskripsikan kemampuan pemecahan masalah siswa setelah diajarkan strategi menebak dengan cerdas dan mengujinya.

\section{METODE PENELITIAN}

Jenis penelitian ini adalah penelitian deskriptif yang bertujuan untuk mendeskripsikan kemampuan pemecahan masalah siswa setelah penerapan strategi menebak dengan cerdas dan mengujinya. Penelitian ini dilaksanakan pada siswa kelas X MIPA 4 SMA Negeri 1 Pangkalpinang yang berjumlah 34 orang. Untuk pembahasan lebih mendalam, dipilih dua subjek penelitian melalui teknik purposive sampling. Instrumen penelitian berupa RPP, LKPD, dan tes pemecahan masalah serta rubrik penilaian tes. 
DOI: https://doi.org/10.24127/ajpm.v10i3.3851

RPP dan LKPD digunakan pada pertemuan pertama dan kedua yang proses pembelajarannya dilakukan secara daring melalui zoom. Tes pemecahan masalah digunakan untuk melihat kemampuan pemecahan masalah siswa setelah diajarkan strategi menebak dengan cerdas dan mengujinya. Tes ini dilakukan pada pertemuan ketiga yang dilaksanakan secara daring melalui zoom dan tatap muka di ruang kelas X MIPA 4 dalam waktu yang bersamaan.

Soal tes terdiri dari dua buah soal dalam bentuk uraian pada materi SPLTV. Hasil tes kemudian dianalisis dengan menentukan skor sesuai dengan tahapan pemecahan masalah Polya yang dapat dilihat pada Tabel 1.

Tabel 1. Pedoman penskoran kemampuan pemecahan masalah.

\begin{tabular}{|c|c|c|c|}
\hline Aspek yang Dinila & & Respon Siswa terhadap Permasalahan & Skor \\
\hline Memahami & 1) & Tidak menjawab & 0 \\
\hline \multirow[t]{2}{*}{ Permasalahan } & 2) & $\begin{array}{l}\text { Terdapat kesalahan dalam memahami dan } \\
\text { menafsirkan permasalahan }\end{array}$ & 1 \\
\hline & 3) & $\begin{array}{l}\text { Benar dalam memahami dan menafsirkan } \\
\text { permasalahan }\end{array}$ & 2 \\
\hline $\begin{array}{l}\text { Menentukan } \\
\text { Rencana yang }\end{array}$ & 1) & $\begin{array}{l}\text { Tidak membuat rencana apapun atau rencana yang } \\
\text { dibuat tidak relevan }\end{array}$ & 0 \\
\hline \multirow[t]{3}{*}{ Tepat } & 2) & $\begin{array}{l}\text { Benar dalam menentukan rencana namun jawaban } \\
\text { tidak tepat }\end{array}$ & 1 \\
\hline & 3) & $\begin{array}{l}\text { Benar dalam menentukan rencana dan mengarah ke } \\
\text { jawaban yang benar }\end{array}$ & 2 \\
\hline & 1) & $\begin{array}{l}\text { Tidak melaksanakan rencana atau melaksanakan } \\
\text { rencana yang tidak relevan }\end{array}$ & 0 \\
\hline \multirow[t]{3}{*}{ Rencana } & 2) & $\begin{array}{l}\text { Melaksanakan rencana dengan benar namun terdapat } \\
\text { kesalahan }\end{array}$ & 1 \\
\hline & 3) & $\begin{array}{l}\text { Melaksanakan rencana dengan benar dan } \\
\text { mendapatkan hasil yang benar }\end{array}$ & 2 \\
\hline & 1) & $\begin{array}{l}\text { Tidak melakukan pemeriksaan atau prosedur } \\
\text { pemeriksaan tidak jelas }\end{array}$ & 0 \\
\hline Kembali & 2) & Terdapat kesalahan dalam melakukan pemeriksaan & 1 \\
\hline $\begin{array}{l}\text { Jawaban yang } \\
\text { Telah Dikerjakan }\end{array}$ & 3) & $\begin{array}{l}\text { Memeriksa kembali jawaban dan Langkah -langkah } \\
\text { pengerjaan dengan benar }\end{array}$ & 2 \\
\hline
\end{tabular}

Setelah dilakukan penskoran sesuai dengan tabel 1, kemudian skor yang diperoleh dikonversi dalam rentang 0100 dan ditentukan kategori pemecahan masalahnya.

\section{HASIL DAN PEMBAHASAN Pertemuan Pertama}

Siswa dibagi ke dalam kelompok kecil melalui breakout room ke dalam 7 kelompok dimana tiap kelompok berisikan 5 orang dengan kemampuan heterogen. Seluruh kelompok dapat menyelesaikan permasalahan yang ada di LKPD dengan tepat sesuai dengan empat tahapan Polya. Terdapat 2 kelompok yang menjawab dengan menggunakan strategi menebak dengan cerdas dan mengujinya, 5 kelompok lainnya menggunakan strategi melihat dari sudut pandang lain. Adanya variasi dalam menyelesaikan permasalahan 
sejalan dengan ungkapan Posamentier \& Krulik (1998) dan Budhi \& Kartasasmita (2015) dalam bukunya yaitu dalam menyelesaikan suatu permasalahan bisa digunakan berbagai macam strategi. Setelah mengerjakan LKPD, kelompok siswa yang menyelesaikan permasalahan dengan tebakan melakukan pemaparan sehingga setiap kelompok mengetahui strategi baru dan dapat diaplikasikan pada LKPD pertemuan kedua. Hal ini sejalan dengan pendapat Tanti, dkk (2020) bahwa dengan adanya pemaparan terhadap hasil kerja siswa, siswa dapat mendiskusikan dan menanggapi hasil pekerjaan teman yang berbeda dengannya sehingga dapat menumbuhkan pengetahuan baru.

\section{Pertemuan Kedua}

Seluruh kelompok dapat menyelesaikan permasalahan yang ada di LKPD dengan tepat sesuai empat tahapan Polya dan menggunakan strategi menebak dengan cerdas dan mengujinya. Hal ini dikarenakan adanya pemaparan pada pertemuan pertama sehingga siswa mengetahui strategi baru yang dapat membantu siswa menyelesaikan permasalahan dengan mudah dan tepat. Pada saat menjawab, seluruh kelompok menyadari bahwa kata kunci yang ada di permasalahan adalah harga $1 \mathrm{~kg}$ tiap buah adalah kelipatan
Rp10.000 sehingga tebakan yang dibuat dimulai dari Rp10.000 dan seterusnya.

\section{Pertemuan Ketiga}

Tes berisi 2 soal pemecahan masalah berbentuk uraian dengan skor maksimal 8 untuk tiap soal. Hasil tes siswa dapat dilihat dari Tabel 2.

Tabel 2. Kategori siswa berdasarkan hasil tes.

\begin{tabular}{ccc}
\hline Nilai & Kategori & $\boldsymbol{f}$ \\
\hline $80<N A \leq 100$ & Sangat Baik & 14 \\
$60<N A \leq 80$ & Baik & 12 \\
$40<N A \leq 60$ & Cukup & 3 \\
$20<N A \leq 40$ & Kurang & 4 \\
$0 \leq N A \leq 20$ & Sangat Kurang & 1 \\
\hline
\end{tabular}

Setelah diperoleh data seperti pada Tabel 2, kemudian dihitung ratarata hasil tes siswa dan diperoleh hasil sebesar 69,85 (kategori baik). Berdasarkan Tabel 2, terlihat bahwa sudah banyak siswa yang berada dalam kategori sangat baik. Kemudian, dipilih dua subjek yaitu S1 (kategori sangat baik) dan S2 (kategori cukup) untuk pembahasan lebih mendalam.

\section{Kemampuan Pemecahan Masalah S1}

Gambar 1 dan 2 menunjukkan hasil pekerjaan S1 pada soal nomor 1 dan 2 .

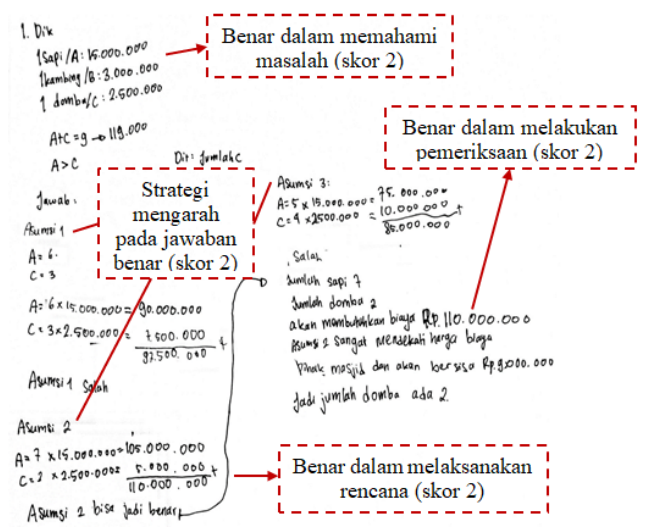

Gambar 1. Jawaban S1 pada soal nomor 1 
DOI: $\underline{\text { https://doi.org/10.24127/ajpm.v10i3.3851 }}$

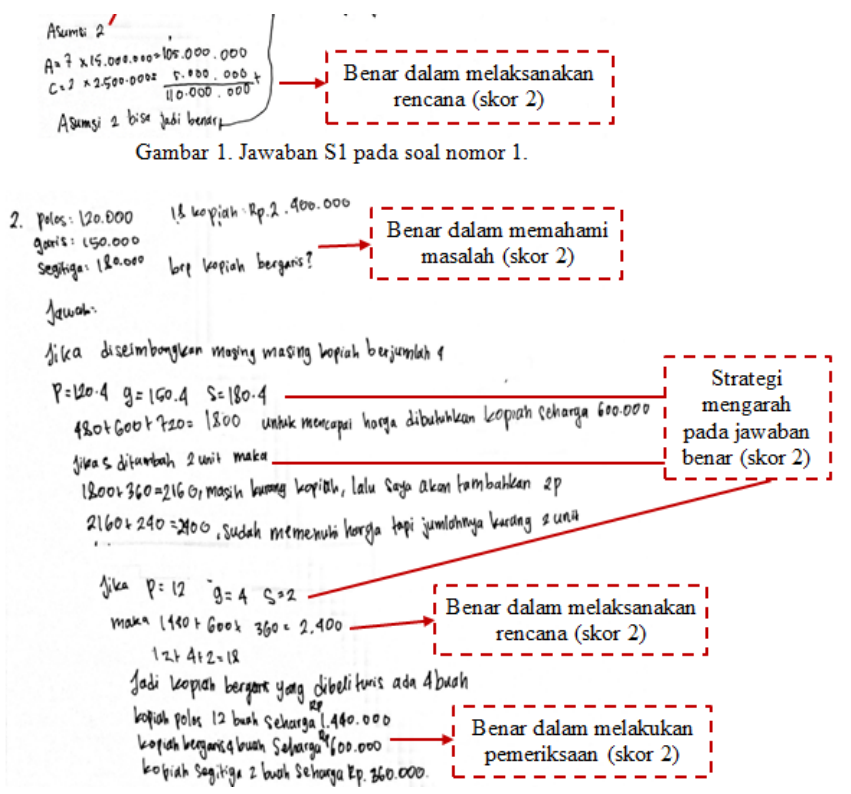

Gambar 2. Jawaban S1 pada soal nomor 2

Dari gambar 1 dan 2, terlihat bahwa S1 menggunakan strategi menebak dengan cerdas dan mengujinya dengan tepat. S1 mendapat skor maksimal pada tiap soal yaitu 8. S1 mampu melaksanakan keempat tahapan Polya dengan baik. Ini sejalan dengan penelitian penelitian Netriwati (2016) dan Saputri \& Mampouw (2018) yang mengungkapkan bahwa siswa yang berkemampuan tinggi dapat memahami permasalahan, menentukan rencana yang tepat, melaksanakan rencana, dan memeriksa kembali jawaban yang telah dikerjakan dengan tepat.

\section{Kemampuan Pemecahan Masalah S2}

Hasil pekerjaan S2 pada soal nomor 1 dapat dilihat pada Gambar 3.

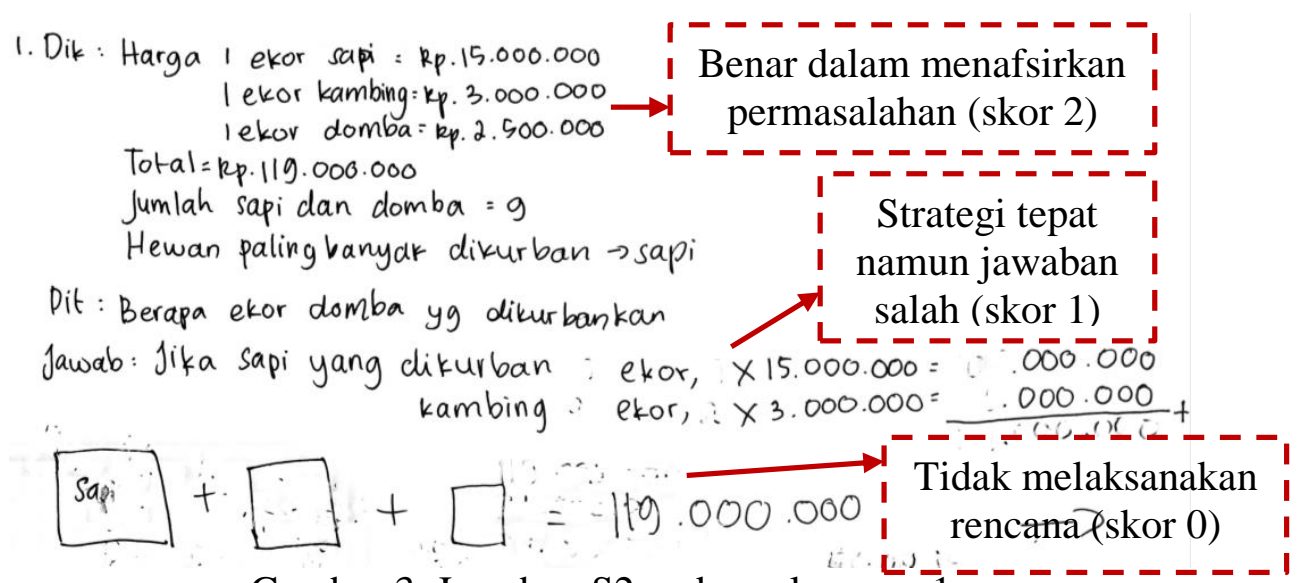

Gambar 3. Jawaban S2 pada soal nomor

Dari gambar 3, terlihat S2 dapat menafsirkan permasalahan dengan benar. Dari jawaban S2, rencana yang akan digunakan untuk menyelesaikan permasalahan adalah dengan menebak.
Ini terlihat dari S2 membuat perkalian antara harga hewan dan banyak hewan. Namun, S2 tidak melaksanakan rencana tersebut dan tidak dapat menyelesaikan permasalahan dengan tepat. 
DOI: https://doi.org/10.24127/ajpm.v10i3.3851

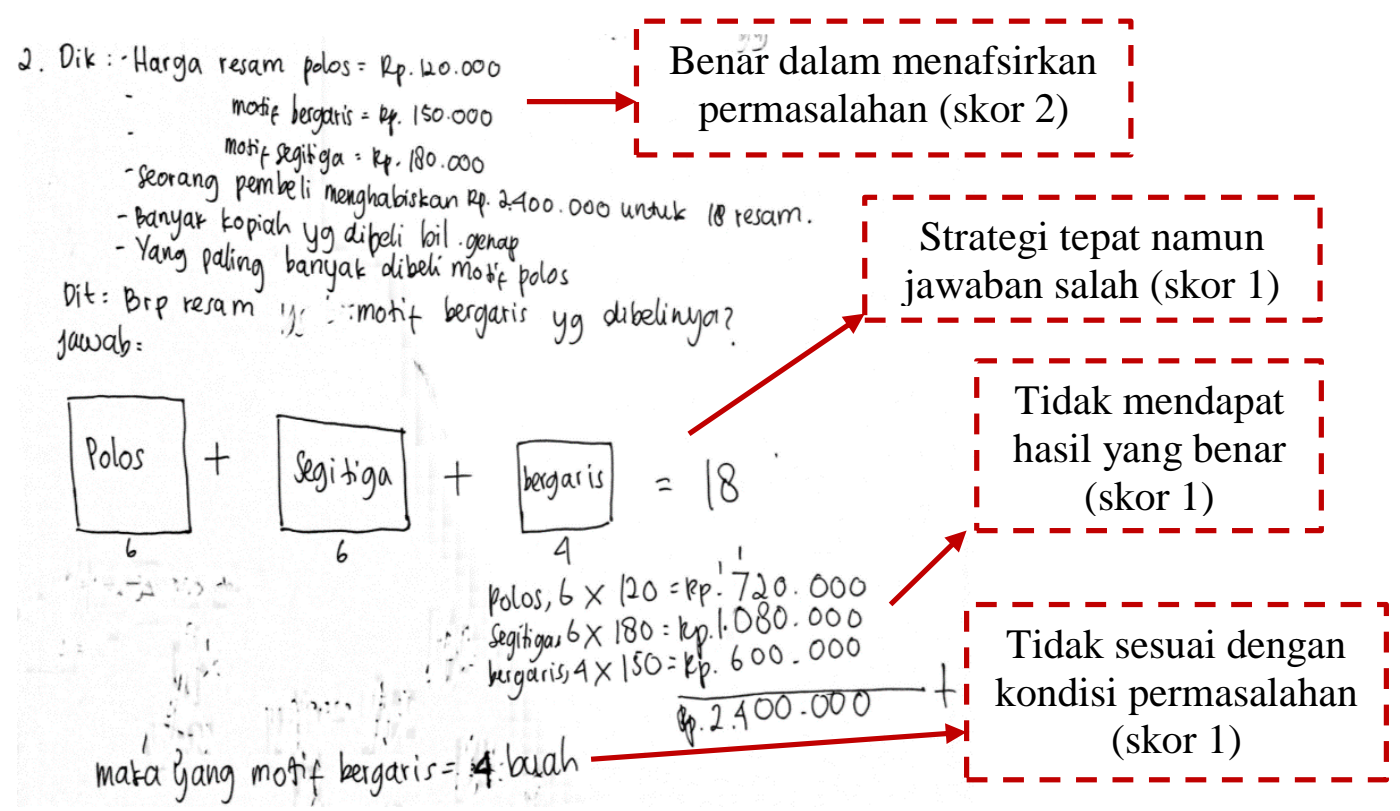

Gambar 4. Jawaban S2 pada soal nomor 2.

Hasil pekerjaan S2 pada soal nomor 2 dapat dilihat pada Gambar 4. Dari gambar 4, terlihat bahwa S2 dapat menafsirkan permasalahan dengan benar. Lalu, terlihat juga bahwa strategi yang digunakan oleh S2 adalah menebak dengan cerdas dan mengujinya walaupun jawaban yang didapat kurang tepat. Walaupun S2 tidak menuliskan secara langsung rencana ataupun membuat model matematikanya namun, S2 langsung melaksanakan rencananya. S2 menebak bahwa kopiah resam polos yang dibeli sebanyak 6 buah, kopiah resam segitiga sebanyak 6 buah, dan kopiah resam bergaris sebanyak 4 buah. Tebakan ini kemudian diuji dengan mengalikan banyaknya kopiah resam dengan harga pada masing-masing motif. Walaupun total harga pembeliannya Rp2.400.000, S2 menghiraukan kondisi permasalahan bahwa kopiah resam yang paling banyak dibeli adalah kopiah resam polos sehingga jawaban yang didapat kurang tepat.

Dari hasil penelitian di atas, tahap memahami permasalahan dapat dilalui dengan baik oleh siswa. Ini dikarenakan pada saat pembelajaran, siswa dibiasakan untuk melihat informasi apa saja yang dibutuhkan untuk menyelesaikan permasalahan. Hal ini sejalan dengan hasil penelitian Ariani et al (2017), Akbar et al (2018), Novitasari \& Wilujeng (2018), Putra et al (2018), dan Zulfitri et al (2019).

Pada tahap menentukan rencana yang tepat, siswa menggunakan strategi menebak dengan cerdas dan mengujinya. Ini dikarenakan pada saat pembelajaran siswa telah diajarkan bagaimana menggunakan strategi menebak dengan cerdas dan mengujinya dalam menyelesaikan permasalahan. Ini sejalan dengan Polya (1973) yang mengungkapkan bahwa pada tahap ini siswa akan mengingat apakah ia pernah menemukan permasalahan serupa dan melihat hubungan antara apa yang diketahui dan yang tidak diketahui dalam permasalahan. Namun di sisi lain, siswa tidak menuliskan secara langsung rencana yang dibuat ataupun membuat model matematikanya tetapi langsung melaksanakan rencananya. Hal ini dikarenakan siswa tidak terbiasa 
dan masih bingung dalam menuliskan rencana secara langsung. Ini terlihat pada saat proses pembelajaran, seluruh kelompok masih bingung dalam menuliskan secara formal ataupun langsung rencana yang akan digunakan namun mereka tahu dan paham apa yang harus dilakukan untuk menyelesaikan permasalahan. Karena keterbatasan waktu, siswa tidak diberi soal latihan sehingga siswa semakin tidak terbiasa dalam menuliskan rencana secara tertulis. Hal ini sejalan dengan hasil penelitian Akbar et al (2018) yang mengungkapkan bahwa siswa tidak dibiasakan untuk menuliskan rencana yang dibuat namun langsung menyelesaikan permasalahan tanpa membuat model matematikanya terlebih dahulu. Sayangnya, peneliti tidak melakukan wawancara untuk mengetahui secara jelas dan terperinci strategi yang digunakan oleh siswa.

$$
\text { Pada tahap melaksanakan }
$$
rencana, siswa yang berada dalam kategori sangat baik membuat tebakan dengan menganalisis permasalahan terlebih dahulu sehingga pada saat menguji tebakan, siswa dengan cepat menemukan solusi permasalahan. Ini sejalan dengan hasil penelitian Saputri \& Mampouw (2018), siswa yang berkemampuan tinggi dapat membuat langkah penyelesaian dengan tepat dan mendapatkan jawaban yang tepat. Namun, terlihat masih ada siswa bingung dengan apa yang ingin dikerjakan. Ini dikarenakan siswa tidak membuat rencana secara tertulis sehingga siswa bingung untuk menentukan langkah apa yang harus dikerjakan selanjutnya. Ini sejalan dengan dengan hasil penelitian Astuti et al (2020) yaitu siswa yang tidak membuat rencana secara tertulis akan mengalami kesulitan dalam melaksanakan rencana.
Pada tahap memeriksa kembali jawaban yang telah dikerjakan, masih ada siswa yang tidak lagi memeriksa apakah solusi yang didapat sesuai dengan kondisi permasalahan karena siswa percaya bahwa solusi yang didapat merupakan solusi yang paling tepat. Ini sejalan dengan hasil penelitian Ariani et al (2017) yang mengungkapkan bahwa siswa tidak terbiasa untuk melakukan pemeriksaan setelah solusi didapat. Pada saat proses pembelajaran juga, peneliti tidak memberikan soal latihan ataupun pekerjaan rumah sehingga siswa semakin tidak terbiasa untuk melakukan pemeriksaan jawaban.

Karena pembelajaran berlangsung secara daring, peneliti kurang maksimal dalam melihat, memantau, dan mengarahkan siswa untuk memahami permasalahan. Peneliti hanya bisa menanyakan dimana letak kesulitan siswa dan baru melihat pekerjaan siswa setelah siswa mengumpulkan hasil pekerjaannya yang kemudian dievaluasi dan dibahas pada pertemuan selanjutnya agar tidak terjadi kesalahan serupa. Ini sejalan dengan kendala yang dihadapi oleh Kartika \& Hiltrimartin (2019) yaitu kemampuan peneliti kurang maksimal dalam mengarahkan siswa untuk memahami permasalahan. Waktu pembelajaran yang sangat terbatas yaitu $2 \times 25$ menit membuat siswa tidak diberikan soal latihan sehingga siswa masih belum terbiasa untuk menyelesaikan permasalahan. Pada saat tes pemecahan masalah, peneliti tidak membuat perintah dengan jelas agar siswa menyelesaikan permasalah sesuai dengan 4 tahapan Polya sehingga siswa tidak menuliskan rencana apa yang akan digunakannya serta siswa juga tidak terbiasa untuk menuliskan secara formal rencana yang dibuat. 


\section{KESIMPULAN DAN SARAN}

Berdasarkan hasil penelitian, siswa dengan kemampuan sangat baik mampu melaksanakan keempat tahapan Polya dengan baik dan siswa dengan kemampuan cukup dapat memahami permasalahan dengan baik namun masih kurang dalam melaksanakan rencana. Dengan mengajarkan strategi menebak dengan cerdas dan mengujinya dalam pembelajaran, dapat menambah pengetahuan siswa dalam menyelesaikan permasalahan.

Hasil penelitian ini dapat digunakan sebagai acuan agar peneliti lain tergerak untuk melakukan penelitian mengenai strategi pemecahan masalah yang lainnya. Dalam melakukan penelitian, peneliti diharapkan untuk melakukan pemberian soal latihan sebagai pemantapan terhadap apa yang diajarkan.

\section{DAFTAR PUSTAKA}

Akbar, P., Hamid, A., Bernard, M., \& Sugandi, A. I. (2018). Analisis Kemampuan Pemecahan Masalah Dan Disposisi Matematik Siswa Kelas XI SMA Putra Juang dalam Materi Peluang. Jurnal Cendekia: Jurnal Pendidikan Matematika, 2(1), 144-153.

Ariani, S., Hartono, Y., \& Hiltrimartin, C. (2017). Kemampuan Pemecahan Masalah Matematika Siswa pada Pembelajaran Matematika Menggunakan Strategi Abduktif-Deduktif di SMA Negeri 1 Indralaya Utara. Jurnal Elemen, 3(1), 25-34.

Astuti, N. H., Rusilowati, A., Subali, B., \& Marwoto, P. (2020). Analisis Kemampuan Pemecahan Masalah Model Polya Materi Getaran, Gelombang, dan Bunyi Siswa SMP. UPEJ: Unnes Physics Education Journal, 9(1), 1-8.
Asy'ari, M. F., Siswono, T. Y. E., \& Lukito, A. (2020). Kompetensi Strategis Siswa dalam Menyelesaikan Persoalan Program Linear Ditinjau dari Kecemasan Matematika. Math Didactic: Jurnal Pendidikan Matematika, 6(1), 98-109.

Ayuningrum, S. M., \& Setiawan, R. (2018). Analisis Penggunaan Strategi Menerka lalu Menguji Kembali dan Melihat dari Sudut Pandang Lain dalam Matematika Non Rutin untuk Penyelesaian Mencari Nilai x pada suatu Persamaan. Jurnal Pendidikan Matematika Dan Matematika (JPPM) Solusi, 2(1), 63-78.

Azmi, M. P. (2017). Penerapan Pendekatan ConcreteRepresentational-Abstract (CRA) Berbasis Intuisi untuk Meningkatkan Kemampuan Komunikasi Matematik Siswa SMP. AKSIOMA: Jurnal Program Studi Pendidikan Matematika, 6(1), 68-80.

Budhi, W. S., \& Kartasasmita, B. G. (2015). Berpikir Matematis Matematika untuk Semua. Erlangga.

Damayanti, N. W. (2017). Praktik Pemberian Scaffolding oleh Mahasiswa Pendidikan Matematika pada Mata Kuliah Strategi Belajar Mengajar (SBM) Matematika. LIKHITAPRAJNA. Jurnal Ilmiah Fakultas Keguruan Dan Ilmu Pendidikan Likhitaprajna, 18(1), 85-95.

Dini, M., Nuraeni, \& Anita, I. . (2018). Meningkatkan Kemampuan Pemahaman Matematis Siswa SMK Menggunakan Pendekatan Kontekstual pada Materi SPLTV. Indomath: Indonesia Mathematics Education, 1(1), 49-54. 
DOI: https://doi.org/10.24127/ajpm.v10i3.3851

Hartono, Y. (Ed.). (2014). Matematika: Strategi Pemecahan Masalah. Graha Ilmu.

Isharyadi, R. (2018). Pengaruh Penerapan Pendekatan

Kontekstual

Terhadap

Peningkatan Kemampuan

Pemecahan Masalah Matematis

Siswa. AKSIOMA Jurnal

Program Studi Pendidikan

Matematika, 7(1), 48-55.

Kartika, M., \& Hiltrimartin, C. (2019).

Penerapan Model Eliciting

Activities (MEAs) dalam

Pembelajaran Matematika Materi

Relasi dan Fungsi. Jurnal

Gantang, 4(2), 161-168.

Mutia, Rochmad, \& Isnarto. (2021). Pentingkah Sebuah Intuisi dalam Pembelajaran Matematika? PRISMA: Prosiding Seminar Nasional Matematika, 4, 369374.

NCTM. (2000). Principles and Standards for School Mathematics. National Council of Teachers of Mathematics (NCTM).

Netriwati. (2016). Analisis Kemampuan Pemecahan Masalah Matematis Berdasarkan Teori Polya Ditinjau dari Pengetahuan Awal Mahasiswa IAIN Raden Intan Lampung. Al-Jabar: Jurnal Pendidikan Matematika, 7(2), 181-190.

Novitasari, \& Wilujeng, H. (2018). Analisis Kemampuan Pemecahan Masalah Matematika Siswa SMP Negeri 10 Tangerang. Prima: Jurnal Pendidikan Matematika, 2(2), 137-147.

Polya. (1973). How to Solve it: A New Aspect of Mathematical Method (2nd ed.). Princeton University Press.

Posamentier, A. S., \& Krulik, S. (1998).
Problem-Solving Strategies for Efficient and Elegant Solutions: A Resource for the Mathematics Teacher. Corwin Press Inc.

Putra, H. D., Thahiram, N. F., Ganiati, M., \& Nuryana, D. (2018). Kemampuan Pemecahan Masalah Matematis Siswa SMP pada Materi Bangun Ruang. JIPM (Jurnal Ilmiah Pendidikan Matematika), 6(2), 82-90.

Riffyanti, L., \& Setiawan, R. (2017). Analisis Strategi Langkah Mundur dan Bernalar Logis dalam Menentukan Bilangan dan Nilainya. AKSIOMA: Jurnal Program Studi Pendidikan Matematika, 6(1), 115-127.

Sanjaya, A., Johar, R., Ikhsan, M., \& Khairi, L. (2018). Students' Thinking Process in Solving Mathematical Problems based on the Levels of Mathematical Ability. Journal of Physics: Conference Series, 1088, 012116.

Saputri, J. R., \& Mampouw, H. L. (2018). Kemampuan Pemecahan Masalah dalam Menyelesaikan Soal Materi Pecahan oleh Siswa SMP ditinjau dari Tahapan Polya. Math Didactic: Jurnal Pendidikan Matematika, 4(2), 146-154.

Sari, P. P. (2016). Analisis Kasus Rendahnya Prestasi Belajar Matematika Siswa pada Materi Irisan Kerucut dan Solusi Pemecahannya di Kelas XI IA 2 SMA IT Nur Hidayah. Konferensi Nasional Penelitian Matematika Dan Pembelajarannya (KNPMP I), 449-458.

Sukmana, A. (2011). Profil Berpikir Intuitif Matematik. In Lembaga Penelitian dan Pengabdian kepada Masyarakat Universitas Katolik Parahyangan. http://journal.unpar.ac.id/index.ph 
DOI: https://doi.org/10.24127/ajpm.v10i3.3851

p/rekayasa/article/download/105/9 2

Susilawati, E., Syaf, A. H., \& Susilawati, W. (2017). Pendekatan Eksplorasi Berbasis Intuisi pada Kemampuan Pemecahan Masalah Matematis. Jurnal Analisa, 3(2), 138-147.

Tanti, Rahim, U., \& Samparadja, H. (2020). Pengaruh Model Problem Based Learning terhadap Kemampuan Pemecahan Masalah Matematis Siswa Kelas VII SMP Negeri 14 Kendari. Jurnal Penelitian Pendidikan Matematika, 8(2), 169-182.

Wahyudi, \& Anugraheni, I. (2017). Strategi Pemecahan Masalah Matematika. Satya Wacana University Press.

Zulfitri, H., Aisyah, N., \& Indaryanti. (2019). Analisis Kemampuan Pemecahan Masalah Matematika Setelah Pembelajaran dengan Pendekatan MEAs pada Materi Sistem Persamaan Linier Tiga Variabel. Jurnal Gantang, 4(1), 7-13. 